\title{
42. THE ALTERATION AND AGING OF THE BASALTIC LAYER OF THE SEA FLOOR: OXYGEN ISOTOPE EVIDENCE FROM DSDP/IPOD LEGS 51, 52, AND 53
}

\author{
Karlis Muehlenbachs, Department of Geology, University of Alberta, Edmonton, Alberta, Canada
}

\begin{abstract}
The $\delta^{18} \mathrm{O}$ values of 108 basaltic samples from Holes $417 \mathrm{~A}, 417 \mathrm{D}$, and $418 \mathrm{~A}$ range from 6.0 to $26.4 \%$. The analyses of separated igneous minerals and anhydrous basalts prove that initially the magmas had $\delta^{18} \mathrm{O}$ values of $5.8 \%$, identical to all other unaltered mid-ocean ridge basalts. The highest $\delta^{18} \mathrm{O}$ samples in all three holes are highly altered hyaloclastites, breccias, and flow margins. The $\delta^{18} \mathrm{O}$-enriched nature of the basalts, in contrast to the normal $\delta^{18} \mathrm{O}$ of igneous minerals, the high $\delta^{18} \mathrm{O}$ values of 29 carbonates and one clay, prove that the wide variability of $\delta^{18} \mathrm{O}$ values in the samples is due to alteration or weathering by cold sea water. A pronounced ${ }^{18} \mathrm{O}$ gradient with depth is found in Hole 417A, and lesser ones are found in the other two holes. The basalts from the lower parts of these holes have the same isotopic compositions as do basalts from young DSDP sites. Basalts from the upper parts of Holes 417D and $418 \mathrm{~A}$ are about as enriched in ${ }^{18} \mathrm{O}$ as are Cretaceous and Jurassic samples from some previous DSDP legs. Those of Hole 417A are much richer in ${ }^{18} \mathrm{O}$. Analyses of carbonates indicate a geothermal gradient of about $10^{\circ} \mathrm{C} / 100$ meters in Hole $417 \mathrm{~A}$ but $5^{\circ} \mathrm{C} / 100$ meters in $418 \mathrm{~A}$. The general pattern of $\delta^{18} \mathrm{O}$ of DSDP basalts with age is that of a rapid increase to about $7.5 \%$ in the first 10 to $20 \mathrm{~m}$.y., followed by a much slower rise to about $9 \%$. This pattern is strikingly similar to that observed for changes in seismic velocity in the upper crust, suggesting that low-temperature alteration or weathering causes the progressive change in geophysical properties associated with the aging of the sea floor.

A simple model of the low-temperature alteration of the oceanic crust can be deduced from comparisons of the $\delta^{18} \mathrm{O}$ data from Holes $417 \mathrm{~A}$, 417D, and 418A with analyses from other DSDP and dredged basalts of known age. The new sea floor is open to cold sea water circulation, which weathers the basalts more or less uniformly to a depth of at least 600 meters. The massive circulation ceases after about 10 m.y., but that is sufficient time to have had the $\delta^{18} \mathrm{O}$ of the rocks raised to about $7.5^{\%} \%$. Some low-temperature alteration proceeds in the upper few hundred meters of the old oceanic crust but at a much slower rate and at a slightly warmer temperature, causing the ${ }^{18} \mathrm{O}$-gradients mentioned above. In addition, there are highly transmissive units throughout the crust through which sea water can circulate for much longer times ( 25 to $50 \mathrm{~m}$.y.). The geochemical differences between Holes $417 \mathrm{~A}$ and $417 \mathrm{D}$ or $418 \mathrm{~A}$ can be attributed to the exposure of $417 \mathrm{~A}$ to cold sea water for a much longer period.
\end{abstract}

\section{INTRODUCTION}

Qualitatively, the oxygen isotope geochemistry of the sea floor is well understood. Numerous analyses of dredged and drilled basalts substantiate the following conclusions. (1) The $\delta^{18} \mathrm{O}$ of fresh unaltered basalts, or primary igneous minerals separated from altered rock, is remarkably uniform, $5.8 \pm 0.3 \%$ (Taylor, 1968; Muehlenbachs and Clayton, 1972a; Pineau et al., 1976; Muehlenbachs, 1976, 1977a, b). (2) The preceding studies and that of Garlick and Dymond (1970) show, however, that most basalts recovered from the sea floor are enriched in ${ }^{18} \mathrm{O}$ because of lowtemperature alteration or weathering. These ${ }^{18} \mathrm{O}$-enriched basalts are also enriched in $\mathrm{H}_{2} \mathrm{O}$. (3) The $\delta^{18} \mathrm{O}$ and water content are strongly correlated as in Figure 1, and are best explained as a mixing line between anhydrous fresh basalt and high- ${ }^{18} \mathrm{O}$, water-rich secondary minerals formed from basalt by reaction with cold sea water (Muehlenbachs and Clayton, 1972a). This study also showed that the degree of weathering reflected as an increase of the $\delta^{18} \mathrm{O}$, proceeds uniformly in basalts that are continuously exposed to cold sea water at a rate of about $0.25 \%$ per m.y. (4) Hightemperature alteration $\left(>300^{\circ} \mathrm{C}\right)$ of sea floor rock, on the other hand, causes a decrease in the ${ }^{18} \mathrm{O}$-content (Muehlenbachs and Clayton, 1972b; Stakes and O'Neil, 1977). However, in DSDP samples, such high alteration temperature is rare and has been observed only in plutonic fragments (Muehlenbachs, 1977a). (5) The amount of oxygen ex- 


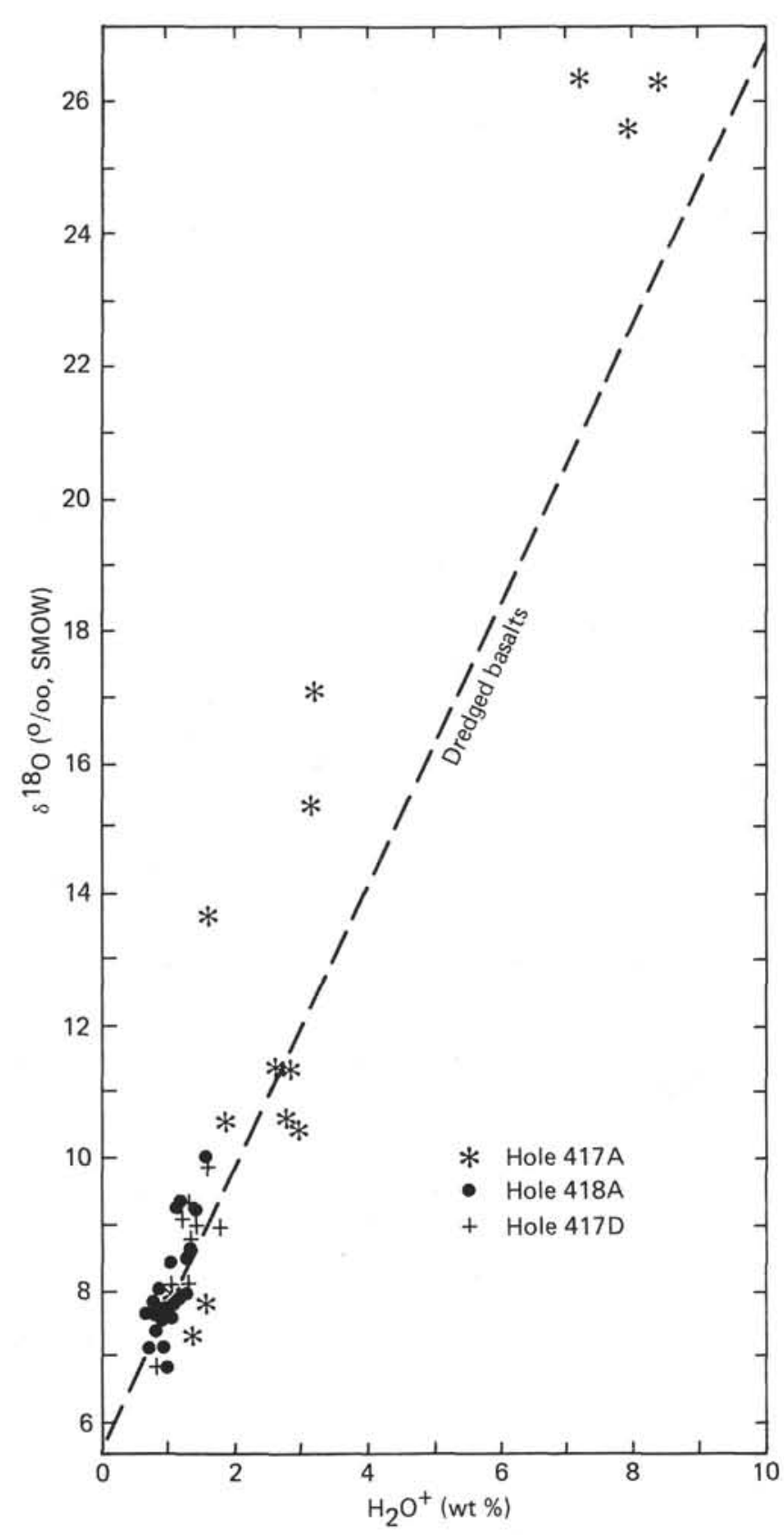

Figure 1. $\delta 18 \mathrm{O}$ versus $\mathrm{H}_{2} \mathrm{O}^{+}$in basalts from Legs 51,52 , and 53. Line represents the trend found in dredged basalts (Muehlenbachs and Clayton, 1972a).

change during sea water-sea floor interaction is so large that this process determines the $\delta^{18} \mathrm{O}$ of the oceans themselves (Muehlenbachs and Clayton, 1976).

Weathering has been observed deep within the young oceanic crust in Holes 332B and 396B (Muehlenbachs, 1977a; Muehlenbachs and Hodges, 1978). Isotopically, the weathering within the young crust is indistinguishable from that found in dredged rocks of equal age, implying that sea water has easy access deep within the new crust as it is being formed (Muehlenbachs, 1974, 1977a; Muehlenbachs and Hodges, 1978). Analyses of older DSDP basalts from Legs 11, 26, 27, and 34 show that the open circulation of cold sea water through the oceanic crust must cease after about 10 m.y. (Muehlenbachs, 1974). Low-temperature alteration in parts of the Cretaceous and Jurassic crust does seem to continue, but at a much slower rate (Muehlenbachs, 1977b).

Quantitatively, much remains to be learned about the alteration of the oceanic crust because of sampling biases in the above-cited studies. Most of the analyzed samples were recovered by dredging the surface of the relatively young crust or by shallow DSDP cores. The only deep samples analyzed have been from the young crust. Fortunately, Legs 51,52 , and 53 recovered Cretaceous basalt from deeper than 500 meters within Layer 2, providing samples for the quantitative evaluation of the weathering and aging of the old oceanic crust.

This paper will describe the ${ }^{18} \mathrm{O}$-geochemistry of basalts from Holes $417 \mathrm{~A}, 417 \mathrm{D}$, and $418 \mathrm{~A}$ and compare them to some unpublished ${ }^{18} \mathrm{O}$ values of other Cretaceous and Jurassic DSDP basalts. The following questions will be discussed and, in some cases, answered. (1) What was the $\delta^{18} \mathrm{O}$ of magmas that built the sea floor at those sites? (2) How altered is the basalt? Does the alteration vary with depth? Does it occur in zones? (3) Are there any intra-hole differences? (4) What was the temperature of alteration? (5) What was the fluid involved: sea water or low ${ }^{18} \mathrm{O}$ connate water (Lawrence et al., 1975)? (6) Do the ${ }^{18} \mathrm{O}$ variations correlate with other bulk chemical variables? (7) How does the alteration of the old crust compare with that observed in the young? Furthermore, conclusions will be drawn about the role alteration plays in the aging of the crust.

\section{METHODS}

\section{Sample Selection}

Samples of basalt were selected for this study by the Shipboard Party of Leg 53, by the Chief Scientists of Legs 51,52 , and 53 (from their shore-based collections), and by the author from Leg 52 samples at the core repository. Avoiding sampling biases is critical to this study because at any one site and from almost any core, material can be selected covering the total possible range of $\delta^{18} \mathrm{O}$ values. The presented data are thought to be representative of the crust because of the large number of samples analyzed and the efforts made to analyze all the different rock types.

\section{Experimental Techniques}

The silicate samples were analyzed by the $\mathrm{BrF}_{5}$ method of Clayton and Mayeda (1963) and the carbonates by the method of McCrea (1950). The data are reported with respect to the SMOW and PDB Standards (Craig, 1957, 1961) for $\delta^{18} \mathrm{O}$ and $\delta^{13} \mathrm{C}$, respectively, in the usual $\delta$ notation. The fractionation factor between $\mathrm{CO}_{2}$ and water was taken to be 1.0407 (see O'Neil et al., 1976, for discussion). The reproducibility of replicate analyses of the very water-rich samples was $\pm 0.2 \%$, whereas that of the anhydrous samples is $\pm 0.1 \%$.

\section{DATA AND DISCUSSION}

The $\delta^{18} \mathrm{O}$ values of basalts, separated minerals, and carbonates from Holes 417A, 417D, and 418A are presented in Tables 1, 2, and 3. The data are also plotted in Figures 2, 3, 4 , and 5 as functions of depth and lithology. The data from 
these holes can be compared with other DSDP basalts on Figure 6 . The data for each individual hole will be discussed separately below.

\section{Hole 417A}

As in other properties, the isotopic pattern observed in samples from Hole 417A differs considerably from that observed in the other nearby sites. In $417 \mathrm{~A}$, there is a marked negative gradient of $\delta^{18} \mathrm{O}$ with depth (Figure 2). Also, some of the rocks of $417 \mathrm{~A}$ are more $\delta^{18} \mathrm{O}$-enriched $(25.4$ to $26.4 \%$ ) than any other DSDP basalts. These are intensely altered hyaloclastites in the top one-third of the hole and are so rich in ${ }^{18} \mathrm{O}$ that they must be totally weathered and in isotopic equilibrium with very cold sea water (Garlick and Dymond, 1970; Savin and Epstein, 1970). The least altered sample from Hole $417 \mathrm{~A}$ is from a massive flow near the bottom of the hole. Its $\delta^{18} \mathrm{O}$ values of $7.0 \%$ imply only 5 to $10 \%$ weathering (according to the model of Muehlenbachs and Clayton, 1972a). In addition to the general trend of decreasing $\delta^{18} \mathrm{O}$ values (i.e., weathering) with depth, Figure 2 indicates that samples from highly permeable layers such as breccia zones and flow margins are also very ${ }^{18} \mathrm{O}$ enriched, even when they occur at depth. The high $-{ }^{18} \mathrm{O}$ nature of such zones is most obvious in Hole 418A (Figure 5) and will be discussed in a later section.

The $\delta^{18} \mathrm{O}$ values of the Hole $417 \mathrm{~A}$ rocks are correlated with water contents (Figure 1). The samples with $\delta^{18} \mathrm{O}$ values less than $12 \%$ fall exactly on the same line as do weathered basalts recovered by dredging (Muehlenbachs and Clayton, 1972a) and by DSDP (Muehlenbachs, 1977a), implying that all these rocks were altered under the same conditions and that all had $\delta^{18} \mathrm{O}$ values $\sim 5.8 \%$ prior to alteration. The samples with $\delta^{18} \mathrm{O}$ values greater than $12 \%$ (more than $30 \%$ weathered) fall above the $\delta^{18} \mathrm{O}$ versus water trend. The most likely explanation for the "excess" ${ }^{18} \mathrm{O}$ content is the abundant ${ }^{18} \mathrm{O}$-rich carbonates disseminated through these specimens.
The isotopic composition of carbonates extracted from some of the basalts ranges for $\delta^{18} \mathrm{O}$ from 30.2 to $27.5 \%$ and for $\delta^{13} \mathrm{C}$ from +0.7 to $-1.6 \%$ (Table 1). Again, there is a negative gradient in $\delta^{18} \mathrm{O}$ with depth (Figure 2), but not as steep as the gradient in the basalts. If it is assumed that the carbonates are calcites that formed in isotopic equilibrium with normal sea water then the temperatures at which they formed ranged from 14.5 to $26.8^{\circ} \mathrm{C}$ (O'Neil et al., 1969). Taking into account the depth at which the samples were recovered, the calculated temperatures correspond to an estimated geothermal gradient of $9.6^{\circ} \mathrm{C} / 100$ meters .

The $\delta^{13} \mathrm{C}$ values of the carbonates (Table 1) are within the range found in marine carbonates. The carbon isotopic composition will be discussed further in the section on Hole 418A.

The geochemistry of Hole $417 \mathrm{~A}$ is intriguing in its extraordinary enrichment of potassium (Donnelly, this volume) and its correlation with $\delta^{18} \mathrm{O}$ (Figure 3). Although it was known that sea floor weathering of basalt increases the potassium content (Hart, 1969), never before have such high enrichments been reported. Pineau et al. (1976) found only a poor correlation between $\delta^{18} \mathrm{O}$ and $\mathrm{K}_{2} \mathrm{O}$ content in some slightly weathered basalts. It appeared that oxygen exchange could begin before the uptake of potassium. But, considering the full range of data from Hole 417A, one can see a strong correlation of $\delta^{18} \mathrm{O}$ with the square root of potassium content (Figure 3) which, significantly, also extrapolates to low $(<0.1 \%)$, normal $\delta^{18} \mathrm{O}(\sim 5.8 \%)$ midocean ridge basalt! It should be noted that the $\delta^{18} \mathrm{O}$ increase in submarine basalts due to weathering is not instantaneous but takes time, about $0.25 \%$ per m.y. (Muehlenbachs and Clayton, 1972a) and therefore, the $\delta^{18} \mathrm{O}$ axis on Figure 3 can be replaced by an "exposure age" to cold sea water. This substitution seems to imply by analogy to dredged basalts that the square root of potassium uptake in Hole $417 \mathrm{~A}$ proceeds linearly with time. The hyaloclastites, however, do not appear to follow this trend. There is no obvious

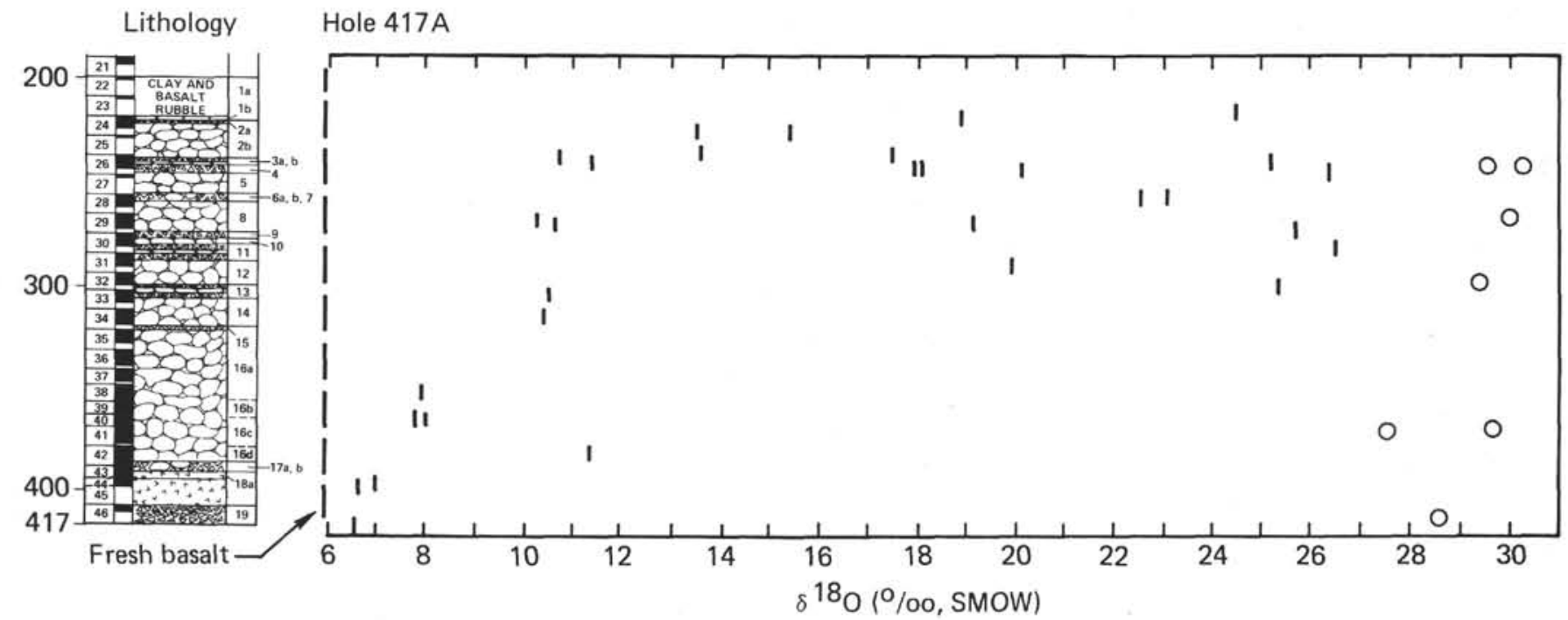

Figure 2. 8180 of basalts (bars) and carbonates (dots) from Hole $417 \mathrm{~A}$ as a function of depth and lithology. The dashed line at $5.8 \%$ represents the initial $\delta 180$ of unaltered basalt. Note that the most altered basalts are from breccia zones or unit boundaries. 
TABLE 1

${ }_{\delta}^{18} \mathrm{O}$ (SMOW) of Hole 417A Basalts

\begin{tabular}{|c|c|c|c|c|}
\hline $\begin{array}{c}\text { Sample } \\
\text { (Interval in } \mathrm{cm} \text { ) }\end{array}$ & Lithology & $\begin{array}{c}\delta^{18} \mathrm{O} \\
\text { Whole } \\
\text { Rock }\end{array}$ & $\begin{array}{c}\delta^{18} \mathrm{O} \\
\text { Carbonate }\end{array}$ & $\begin{array}{c}\delta^{13} \mathrm{C} \\
\text { Carbonate }\end{array}$ \\
\hline $24-2,4$ & & 24.5 & & \\
\hline $24-2,69-74$ & & 18.9 & & \\
\hline $25-1,57$ & F & 15.4 & & \\
\hline $25-1,92-96$ & & 13.5 & & \\
\hline $26-1,31$ & & 17.5 & & \\
\hline $26-1,39$ & $\mathrm{~F}$ & 13.6 & & \\
\hline $26-1,68-71$ & $\mathrm{H}$ & 25.1 & 30.2 & +0.7 \\
\hline $26-2,10$ & $\mathrm{Br}$ & 11.3 & & \\
\hline $26-3,86$ & & 20.1 & & \\
\hline $26-3,99-104$ & & 18.0 & 29.5 & - \\
\hline $26-4,103$ & $\mathrm{Br}$ & 26.3 & & \\
\hline $26-5,72 \mathrm{~A}$ & $\mathrm{~F}$ & 17.1 & & \\
\hline $28-1,36 \mathrm{~A}$ & & 23.1 & & \\
\hline $29-1,92-93$ & & 9.1 & 30.0 & +0.1 \\
\hline $29-3,132$ & & 10.4 & & \\
\hline $29-5,37$ & $\mathrm{~F}$ & 10.6 & & \\
\hline $29-5,37$ & $\mathrm{H}$ & 25.6 & & \\
\hline $30-5,24$ & $\mathrm{H}$ & 26.4 & & \\
\hline $31-2,117$ & & 19.94 & & \\
\hline $32-4,20-29$ & & 25.3 & 29.3 & +1.4 \\
\hline $33-1,106$ & $\mathrm{Br}$ & 10.5 & & \\
\hline $34-5,37 \mathrm{R}$ & $\mathrm{F}$ & 10.4 & & \\
\hline $38-3,70$ & $\mathrm{~F}$ & 8.0 & & \\
\hline $40-2,126-129$ & & 8.0 & 27.5 & -1.6 \\
\hline $40-2,130$ & $\mathrm{~F}$ & 7.8 & & \\
\hline $42-1,110$ & $\mathrm{~F}$ & 11.4 & & \\
\hline $44-2,8$ & $\mathrm{MB}$ & 7.0 & & \\
\hline $44-4,5$ & & 6.8 & & \\
\hline $46-1,23$ & & 6.7 & & \\
\hline $46-3,40-42$ & & 16.7 & 28.5 & +0.8 \\
\hline
\end{tabular}

${ }^{\mathrm{a}} \mathrm{F}=$ basalt flow $; \mathrm{H}=$ hyaloclastite $; \mathrm{Br}=$ breccia $; \mathrm{MB}=$ massive basalt.

explanation for the correlation seen in Figure 3, but considering that it spans $\delta^{18} \mathrm{O}$ values from 7 to $17.1 \%$ and $\mathrm{K}_{2} \mathrm{O}$ from 0.04 to 5.14 wt. per cent, it must contain information about the exact mechanism and rate of formation of secondary minerals in basalt on exposure to cold sea water.

\section{Hole 417D}

The isotopic geochemistry of Hole 417D is simpler than that of Holes 417A and 418A. The total range in $\delta^{18} \mathrm{O}$ values observed in the rocks is 6.8 to $19.2 \%$ (Table 2). The 280 meter-long basalt section displays a mild, negative $\delta^{18} \mathrm{O}$ gradient (Figure 4) being $9 \%$ near the top and about 7.5\% at the bottom. Again the very $\delta^{18} \mathrm{O}$-enriched samples come from breccia zones and flow margins independently of depth.

The $\delta^{18} \mathrm{O}$ values of the basalts are well correlated with water content (Figure 1), but water analyses were available only from the least altered samples. As in Holes 417A and $418 \mathrm{~A}$, the observed trend is indistinguishable from that of other dredged and drilled basalts.

Because the isotopic composition of carbonates from Hole 417D are rather variable, a geothermal gradient cannot be calculated. The $\delta^{18} \mathrm{O}$ values of the carbonates range from 25.8 to $31.5^{\circ} \%$, implying temperatures of formation of $9^{\circ}$ to $36^{\circ} \mathrm{C}$. The $\delta^{18} \mathrm{O}$ value of a $1-\mathrm{cm}$-thick clay vein in Core 52 was $21.3 \%$, also implying formation by relatively cold sea water. The $\delta^{13} \mathrm{C}$ values range from +3.7 to $-1.6 \%$, typical of other DSDP basalts (Muehlenbachs, 1977a, b).

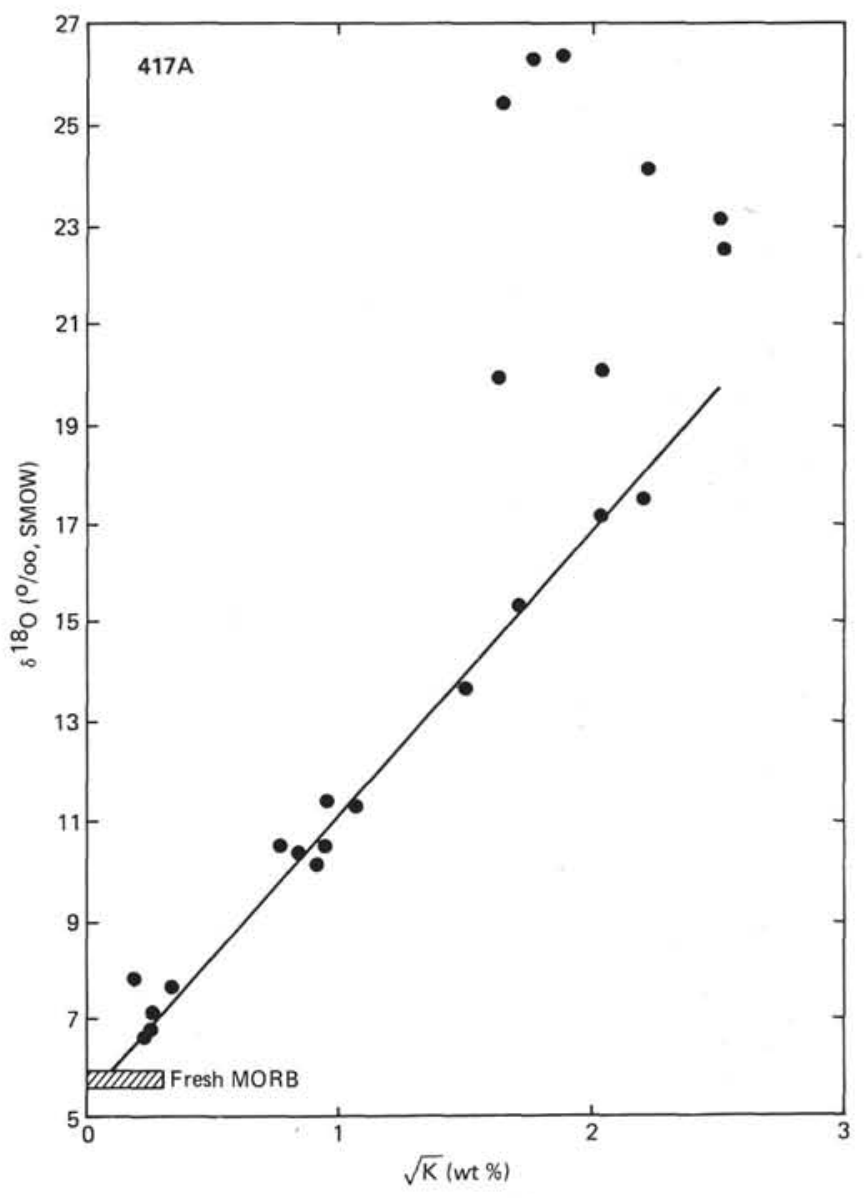

Figure 3. $\delta^{18} O$ of basalts (dots) and hyaloclastites (stars) from Hole $417 \mathrm{~A}$ versus square root of potassium content.

\section{Hole 418A}

Although the alteration of basalts from Hole $418 \mathrm{~A}$ is less spectacular than in $417 \mathrm{~A}$, the hole is much deeper $(540 \mathrm{~m})$ and is probably more representative of the sea floor. The total range in $\delta^{18} \mathrm{O}$ values of the basalts is from 6.0 to $17.7 \%$ (Table 3). Analyses of separated plagioclase and pyroxene from high- ${ }^{18} \mathrm{O}$ basalts (Table 3 , from Cores 74 and 86) again prove that the isotopic composition of these magmas was normal $(\sim 5.8 \%)$ and that the wide variability of $\delta^{18} \mathrm{O}$ found in sea floor basalts is caused by secondary alteration. Petrographic description and chemical composition of many of the samples from Table 3 are given by Scarfe (this volume) and Staudigel et al. (this volume).

The most altered rocks in Hole 418A are the breccias and samples from flow margins (Figure 5), as was noted in Holes 417A and 417D. Disregarding these, one can observe a rough ${ }^{18} \mathrm{O}$ gradient in the less altered rocks of Hole 418A. Basalts from the top half of the hole are about $9 \%$, whereas those from the bottom half are near 7.5\% (Figure 5). A small dike (Core 79) is slightly richer in ${ }^{18} \mathrm{O}$ than the enclosing basalt. All these rocks fit the usual $\delta^{18} \mathrm{O}$ versus water content line (Figure 1) which is diagnostic of sea-floor weathering.

Carbonates both in veins and those disseminated in basalt tend to decrease in ${ }^{18} \mathrm{O}$ content with depth in Hole 418A. 
TABLE 2

${ }_{\delta}^{18} \mathrm{O}$ (SMOW) of Hole 417D Basalts

\begin{tabular}{|c|c|c|c|c|}
\hline $\begin{array}{c}\text { Sample } \\
\text { (Interval in } \mathrm{cm} \text { ) }\end{array}$ & $\begin{array}{c}\delta^{18} \mathrm{O} \\
\text { Whole } \\
\text { Rock }\end{array}$ & $\begin{array}{l}{ }^{1^{18} \mathrm{O}} \\
\text { Other }\end{array}$ & $\begin{array}{c}\delta^{18} \mathrm{O} \\
\text { Carbonate }\end{array}$ & $\begin{array}{c}\delta^{13} \mathrm{C} \\
\text { Carbonate }\end{array}$ \\
\hline $22-4,44-46$ & 9.1 & & 31.5 & +1.2 \\
\hline $26-2,111-112$ & 9.5 & & 29.6 & -0.4 \\
\hline $26-3,40$ & 9.4 & & & \\
\hline $27-7,14$ & 9.1 & & & \\
\hline $28-7,8-10 ; 1 a$ & 9.1 & & 25.9 & +0.8 \\
\hline $29-1,25-28$ & 9.0 & & 30.2 & +1.6 \\
\hline $29-4,24-26$ & 12.1 & & 31.0 & +3.7 \\
\hline $31-4,140$ & 14.8 & & & \\
\hline $31-5,7-10$ & 15.0 & & 27.9 & +0.3 \\
\hline $32-5,60-62$ & 8.7 & & & \\
\hline $33-4,20$ & 7.5 & & & \\
\hline $35-5,126$ & 8.8 & & & \\
\hline $35-5,9$ & 10.0 & & & \\
\hline $35-7,30-31$ & 8.9 & & 30.4 & +2.0 \\
\hline $38-3,123$ & 9.2 & & & \\
\hline $39-1,34-38$ & 14.8 & & & \\
\hline $42-5,115$ & 8.0 & & & \\
\hline $48-6,26-28$ & 8.3 & & & \\
\hline $49-2,23$ & 9.0 & & & \\
\hline $52-2,71-73$ & 9.9 & $21.3^{v}$ & & \\
\hline $52-6,99-101$ & 10.9 & & 26.1 & +2.9 \\
\hline $53-2,61$ & 8.0 & & & \\
\hline $57-3,36-38$ & 19.2 & & & \\
\hline $59-3,111-113$ & 16.0 & & & \\
\hline $60-6,50-54$ & 8.3 & & & \\
\hline $62-1,127-129$ & 8.7 & & & \\
\hline $62-7,7-10$ & 9.0 & & 25.8 & +0.9 \\
\hline $66-3,14-15$ & 9.1 & & 29.0 & +1.8 \\
\hline $66-6,3$ & 7.9 & & & \\
\hline $67-1,34-40$ & 7.0 & & 26.4 & +0.7 \\
\hline $67-4,107-110$ & 7.5 & & & \\
\hline $68-4,20$ & 9.0 & & & \\
\hline $69-1,122$ & 6.8 & & & \\
\hline
\end{tabular}

Note: $v=$ vein.

They range in $\delta^{18} \mathrm{O}$ from 19.6 to $29.7 \%$ (Table 3) and would correspond to temperatures from $75^{\circ}$ to $16^{\circ} \mathrm{C}$ under the usual assumptions of calcite being in equilibrium with normal sea water. These assumptions do not apply to the lowest ${ }^{18} \mathrm{C}$ carbonate (the warmest), because its $\delta^{13} \mathrm{C}$ value of $-13.7 \%$ is peculiar, and carbonates richer in both ${ }^{18} \mathrm{O}$ and ${ }^{13} \mathrm{O}$ are found nearby. Its origin will be discussed in the next paragraph. Disregarding this sample, one can calculate isotopic temperatures of between $30^{\circ}$ and $40^{\circ} \mathrm{C}$, for the bottom of Hole $418 \mathrm{~A}$ and a geothermal gradient between $3^{\circ}$ and $5^{\circ} \mathrm{C}$ per 100 meters.

$\delta^{13} \mathrm{C}$ values of +2 to $-2 \%$ are usually considered indicative of carbonates precipitated inorganically from normal sea water. Low $\delta^{13} \mathrm{C}$ values $\left(<-9^{\circ} \%\right.$ ) imply that the precipitated carbonate ion was produced by biological activity. Such carbonates have already been reported by Anderson and Lawrence (1976) from Leg 35 sediments. Of special interest to this paper is the correlative implication that the low- ${ }^{13} \mathrm{C}$ carbonate $(418 \mathrm{~A}-86-2,109-113 \mathrm{~cm})$ was precipitated from stagnant pore waters instead of circulating sea water. Lawrence et al. (1975) have shown that such pore waters become depleted of ${ }^{18} \mathrm{O}$ because of isotope exchange with basalt. If that were the case with this carbonate, then the calculated temperature is of course meaningless.

\section{Comparison With Other DSDP Basalts}

It has been shown above that $\delta^{18} \mathrm{O}$ values of submarine basalts reflect their alteration history. If the change in physical properties of the oceanic crust with age, such as seismic velocity (Houtz and Ewing, 1976), is a result of progressive alteration, then comparative isotopic studies of different DSDP holes should elucidate the aging of the crust. The previously published ${ }^{18} \mathrm{O}$ analyses of DSDP basalts (Muehlenbachs, 1976, 1977a, b; Anderson and Lawrence, 1976) as well as numerous unpublished analyses are summarized in Figure 6 as a function of age. Almost all of the analyzed samples are enriched in ${ }^{18} \mathrm{O}$, but the older basalts are less altered than if they had been exposed to sea water for a length of time equal to their age.

The observed trend in Figure 6 of an initial rise in $\delta^{18} \mathrm{O}$ during the first 10 to $30 \mathrm{~m} . \mathrm{y}$. and a leveling off thereafter is remarkably similar to the change of seismic velocity measured in the acoustic basement as a function of a crustal age (Houtz and Ewing, 1976, their fig. 9). The synchronous increase in the $\delta^{18} \mathrm{O}$ of basalts and the change in seismic properties of the crust must imply that both are caused by the same low-temperature alteration or submarine weathering (see Hart, 1973, for discussion of the effect of weathering on seismic velocities). Perhaps the suggestion that both may vary with depth (Figures 2 and 5, Whitmarsh, 1978) is additional evidence that the changes in isotopic and seismic data measure the same process.

It is rather surprising that obvious sampling biases have not obscured the above discussions. Of all the sites plotted in Figure 6, only Holes 332B, 396B, and those of this study have penetrated reasonably deeply into the crust. Because they differ greatly in age and in oxygen isotope geochemistry, comparison of these deep holes is very instructive. In contrast to the Cretaceous holes of Legs $51-53$, no ${ }^{18} \mathrm{O}$ gradients with depth were observed in the young Holes 332B (3.5 m.y.) and 396B (13 m.y.) (Muehlenbachs, 1977a, b; Muehlenbachs and Hodges, 1978). Furthermore, breccia zones and flow margins in these holes were not exceptionally enriched in ${ }^{18} \mathrm{O}(<10 \%)$. Most of the massive young basalts, however, are somewhat enriched in ${ }^{18} \mathrm{O}$ because of weathering, but only to about the same degree as those at the bottom of 417D and 418A.

\section{ALTERATION AND AGING OF THE TOP 600 METERS OF SEA FLOOR}

The above discussions and cited studies have shown that basalts from the sea floor are almost always altered. It is of great importance to understand the conditions, and the timing of the processes which alter the crust because these affect a variety of geophysical parameters that characterize the aging of the sea floor.

This report has stressed low-temperature alteration, but it should not be inferred that higher temperature processes are not important in the evolution of the crust. They are present (Muehlenbachs and Clayton, 1972b, 1976; Stakes and O'Neil, 1977), but their products have been sampled by DSDP only rarely. 


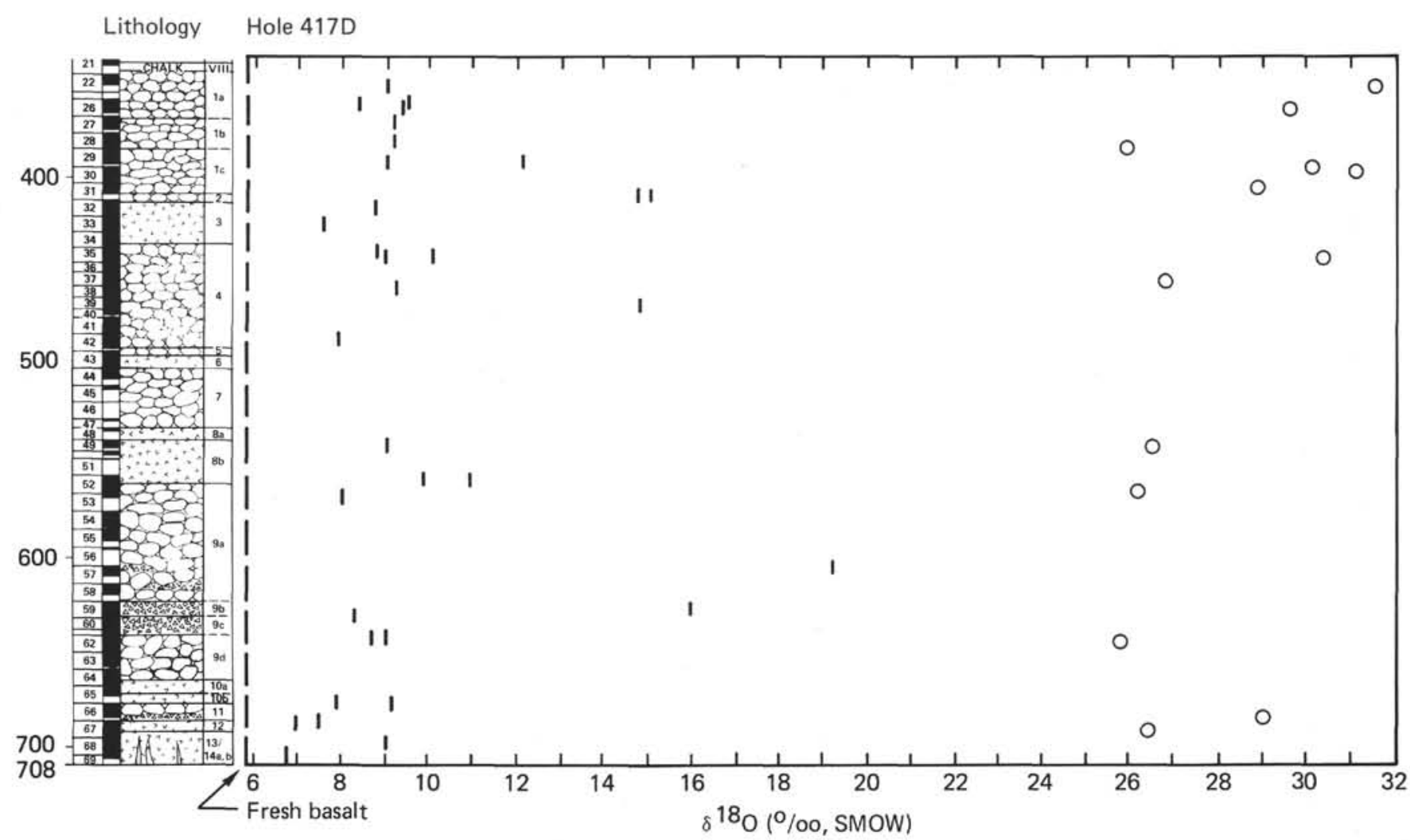

Figure 4. $\delta 180$ of basalts (bars) and carbonates (dots) from Hole 417D as a function of depth and lithology. The dashed line at $5.8 \%$ represents the initial $\delta 180$ of unaltered basalt. Note that the most altered samples are from breccia zones or unit boundaries.

\section{Conditions of Alteration}

The ${ }^{18} \mathrm{O}$-enriched nature of the basalts, the correlation seen in Figure 1, and the ${ }^{18} \mathrm{O}$-rich secondary minerals all indicate that the basalts from Holes 417A, 417D, and 418A were altered by cold sea water circulating through the crust. The exact temperature of alteration is difficult to specify because of two ambiguities. (1) To calculate a temperature from the $\delta^{18} \mathrm{O}$ values of the carbonates or other secondary minerals, one has to assume that they formed in equilibrium with circulating sea water that was present everywhere in amounts so large that its $\delta^{18} \mathrm{O}$ was not lowered by the weathering process. This condition is no doubt met in the young crust (Muehlenbachs, 1977a) but not in the old crust buried by hundreds of meters of sediment (Lawrence et al., 1975). It is likely that the carbonate with $\delta^{13} \mathrm{C}$ of $-13.7 \%$ at the bottom of Hole 418A formed from stagnant low $\delta^{18} \mathrm{O}$ pore water. (2) The other ambiguity is that early secondary minerals which formed from sea water at the lowest possible temperature may re-equilibrate with sea water trapped in pore spaces at a slightly warmer temperature determined by the ambient geothermal gradient.

Two independent lines of evidence indicate that most of the carbonates in Hole 418A may have re-equilibrated. No $\delta^{18} \mathrm{O}$ gradients with depth are evident in the carbonates of Holes 332B and 396B which all yield isotopic temperatures near $0^{\circ} \mathrm{C}$. In contrast, the Cretaceous carbonates imply warmer temperatures of $10^{\circ}$ to $40^{\circ} \mathrm{C}$ that seem to fall on a geothermal gradient. Strontium isotope evidence, however proves that those same carbonates formed when the crust was young (Hart and Staudigel, this volume) so it is likely that their present $\delta^{18} \mathrm{O}$ values reflect re-equilibration with sea water in the present geothermal gradient.

The altered basalts of Hole 417A certainly appear different from those of Holes 417D and 418A. Because of the extreme ${ }^{18} \mathrm{O}$ enrichment observed in the hyaloclastites and carbonates, it is certain that they too were weathered by an excess of cold sea water and that the differences among the holes reflect differences in degree but not of conditions of alteration.

\section{Timing of the Alteration}

The rate and timing of the weathering of the sea floor is governed by the rate of reaction of sea water with basalt and changes in permeability of Layer 2 . The result of these factors can be evaluated quantitatively by comparing the ${ }^{18} \mathrm{O}$ increases in weathered, dredged, and drilled basalts of known age as well as comparing the distribution of ${ }^{18} \mathrm{O}$ with depth in young and old DSDP holes.

The alteration must commence immediately after the crust is formed because the young $(<3.2 \mathrm{~m} . \mathrm{y}$.) DSDP basalts are pervasively weathered (Muehlenbachs, 1977a; Muehlenbachs and Hodges, 1978). The weathering proceeds for some millions of years and then appears to cease because the $\delta^{18} \mathrm{O}$ values of DSDP basalts do not continue to increase with age (Figure 6). The $\delta^{18} \mathrm{O}$ values of the altered basalts from both the young sites and the bottom of the deep Cretaceous holes are approximately the same as those of 
TABLE 3

${ }_{\delta}^{18} \mathrm{O}$ (SMOW) of Hole 418A Basalts

\begin{tabular}{|c|c|c|c|c|}
\hline $\begin{array}{c}\text { Sample } \\
\text { (Interval in } \mathrm{cm} \text { ) }\end{array}$ & $\begin{array}{c}\delta^{18} \mathrm{O} \\
\text { Whole } \\
\text { Rock }\end{array}$ & $\begin{array}{l}\delta^{18} \mathrm{O} \\
\text { Other }\end{array}$ & $\begin{array}{c}\delta^{18} \mathrm{O} \\
\text { Carbonate }\end{array}$ & $\begin{array}{c}{ }^{{ }^{13} \mathrm{C}} \\
\text { Carbonate }\end{array}$ \\
\hline $15-2,0$ & 9.3 & & & \\
\hline $15-2,40-42$ & & & $29.5^{\mathrm{V}}$ & $+1.7^{\mathrm{V}}$ \\
\hline $17-3,40$ & 9.2 & & & \\
\hline $18-4,40$ & 7.8 & & & \\
\hline $19-7,85$ & 8.4 & & $28.5^{\mathrm{V}}$ & $+1.8^{\mathrm{V}}$ \\
\hline $22-1,46-49$ & 8.4 & & & \\
\hline $24-1,59$ & 9.2 & & & \\
\hline $30-3,4$ & 8.0 & & & \\
\hline $37-1,30$ & & & $25.9^{\mathrm{V}}$ & $+1.5^{\mathrm{V}}$ \\
\hline $41-3,100$ & 10.0 & & & \\
\hline $42-3,68$ & 8.6 & & & \\
\hline $45-2,131$ & 8.5 & & $29.7^{\mathrm{V}}$ & $+2.1^{\mathrm{V}}$ \\
\hline $50-1,10$ & 16.3 & & & \\
\hline $50-2,10$ & 11.0 & & & \\
\hline $51-4,34$ & 13.3 & & 24.9 & -2.7 \\
\hline $52-5,75-80$ & 7.9 & & & \\
\hline $52-6,12-14$ & 17.5 & & & \\
\hline $55-2,48-50$ & 17.1 & & & \\
\hline $55-6,15$ & 7.1 & & & \\
\hline $56-6,82-85$ & $\begin{array}{r}17.7 \\
7.8\end{array}$ & & & \\
\hline $\begin{array}{l}57-2,113 \\
59-1,100-104\end{array}$ & 7.8 & & $21.8^{\mathrm{V}}$ & $-0.6^{\mathrm{V}}$ \\
\hline $59-4,102$ & & & $22.2^{\mathrm{V}}$ & - \\
\hline $60-5,41-44$ & 11.5 & & 27.5 & -0.2 \\
\hline $60-5,133$ & 7.7 & & & \\
\hline $62-4,104$ & 7.6 & & & \\
\hline $64-4,82$ & 6.0 & & & \\
\hline $65-1,108-110$ & 17.3 & & & \\
\hline $65-4,3-6$ & 13.0 & & & \\
\hline $\begin{array}{l}68-3,40-42 \\
69-3,63-66\end{array}$ & $\begin{array}{r}13.5 \\
7.1\end{array}$ & & & \\
\hline $\begin{array}{l}09-3,03-00 \\
72-4,13-15\end{array}$ & 10.4 & & & \\
\hline $73-1,127$ & 7.4 & & & \\
\hline $73-2,89-91$ & 10.0 & & & \\
\hline $74-5,63-66$ & 11.7 & $6.0^{\mathrm{Pc}}$ & & \\
\hline $75-3,120-123$ & 10.8 & $5.7^{\mathrm{Px}}$ & & \\
\hline $76-1,4$ & 7.9 & & & \\
\hline $76-2,99$ & 9.5 & & & \\
\hline $76-2,120$ & & & $21.7^{\mathrm{V}}$ & $+0.9^{\mathrm{V}}$ \\
\hline $77-2,47$ & 8.1 & & & \\
\hline $79-4,88$ & 7.5 & $7.9^{\mathrm{D}}$ & & \\
\hline $\begin{array}{l}80-2,123 \\
83-1,22\end{array}$ & 7.1 & & $24.7^{v}$ & $-0.4^{v}$ \\
\hline $86-1,82-85$ & 9.0 & & 26.6 & -0.9 \\
\hline $86-2,109-113$ & 10.1 & $6.0^{\mathrm{Pc}}$ & 19.6 & -13.7 \\
\hline $86-5,29$ & 7.9 & & & \\
\hline
\end{tabular}

Note: $\mathrm{D}=$ Dike $; \mathrm{Pc}=$ Plagioclase $; \mathrm{Px}=$ Pyroxene $; \mathrm{v}=$ Vein.

basalts exposed to sea water for about $10 \mathrm{~m} . \mathrm{y}$. The conclusion to be drawn is that the easy access of sea water to the crust ends by that time (Muehlenbachs, 1974). After the open circulation of sea water ceases, some alteration continues in the top of the basalt section because ${ }^{18} \mathrm{O}$ gradients are observed in basalts from the Cretaceous holes of this study (Figures 2, 4, and 5) but not in the young holes of equal depth (Muehlenbachs, 1977a; Muehlenbachs and Hodges, 1978). The second stage of alteration proceeds at a much slower rate and probably with connate sea water as is evidenced by $\mathrm{Sr}$-isotope analyses (Hart and Staudigel, this volume).

Limited regions of high permeability cross-cut this simple sea-floor model. Sea water can flow through these transmis- sive units for much longer times. Such zones are the extremely ${ }^{18} \mathrm{O}$-rich breccias and flow margins (Figures 2, 4, and 5), zones the permeability of which is known to be very high (D. Johnson, this volume). In the young holes, 332B and $396 \mathrm{~B}$, such zones are not exceptionally enriched in ${ }^{18} \mathrm{O}$ (Muehlenbachs, 1977; Muehlenbachs and Hodges, 1978) because those holes are too young to have had any rock weathered to $\delta^{18} \mathrm{O}$ values above 9 to $10 \%$. The observations that rocks from highly permeable regions in the Cretaceous sites have $\delta^{18} \mathrm{O}$ values of 12 to $19 \%$ imply that flow in them continued for up to $50 \mathrm{~m} . \mathrm{y}$. Anderson et al. (1978) perhaps have observed a geophysical consequence of such transmissive elements in the older crust. They postulated convection within the crust to explain peculiarities in their heat flow survey.

In Hole $417 \mathrm{~A}$ the ${ }^{18} \mathrm{O}$ gradient with depth (Figure 2) is much more pronounced than in its companion holes. Also, some of the uppermost hyaloclastite zones seem to have reached equilibrium with cold sea water. It appears from the above reasoning, that the upper parts of Hole $417 \mathrm{~A}$ had access to sea water for at least $20 \mathrm{~m}$.y. and that the hyaloclastites were exposed to sea water for more than $50 \mathrm{~m} . \mathrm{y}$. This interpretation of the contrasting ${ }^{18} \mathrm{O}$ geochemistry between Hole 417A and Holes 417D and 418A is consistent with the sedimentology of that region and the fact that $417 \mathrm{~A}$ was drilled on a topographic high.

\section{CONCLUSIONS}

This study shows that the $\delta^{18} \mathrm{O}$ values of the basalts from DSDP Legs $51-53$ were normal, $\sim 5.8 \%$, but low-temperature alteration or weathering has enriched them in $\delta^{18} \mathrm{O}$. In contrast to young basalts from DSDP sites, these Cretaceous holes display negative $\delta^{18} \mathrm{O}$ gradients with depth and extreme ${ }^{18} \mathrm{O}$ enrichment of breccias and flow margins. Basalts from the bottom of the Cretaceous cores are altered to about the same extent as those from the young Holes $332 \mathrm{~B}$ and 396B. Carbonates of Holes $417 \mathrm{~A}$ and $418 \mathrm{~A}$ also seem to show a ${ }^{18} \mathrm{O}$ gradient from which one can calculate a maximum geothermal gradient of about $9.6^{\circ} \mathrm{C} / 100$ meters and about $5^{\circ} \mathrm{C} / 100$ meters, respectively.

A simple model for the weathering of the top 600 meters of basalt can be proposed that accounts for the oxygen isotope data from both young and old DSDP sites. The sea floor is pervasively weathered (to about $10 \%$ ) by cold sea water during its first $10 \mathrm{~m} . \mathrm{y}$. After that, massive circulation ceases, except in some localized highly permeable zones in which circulation may continue for another 25 to $50 \mathrm{~m}$.y. Also, some alteration of the upper parts of the old buried crust continues, perhaps to about 20 per cent, but at a much slower rate. It is probable that late alteration is caused by the continued reaction with trapped, stagnant pore water. That some exchange with stagnant, modified sea water occurs can be inferred from the low $\delta^{13} \mathrm{C}$ and $\delta^{18} \mathrm{O}$ value of one carbonate. The proposed model is consistent with strontium isotope studies of the timing of the alteration (Hart and Staudigel, this volume) and measured permeabilities (D. Johnson, this volume). Geophysical data, such as those of changes of seismic properties (Houtz and Ewing, 1976) with age of the crust and details of regional heat flow (Anderson et al., 1978) also appear to support this model. 


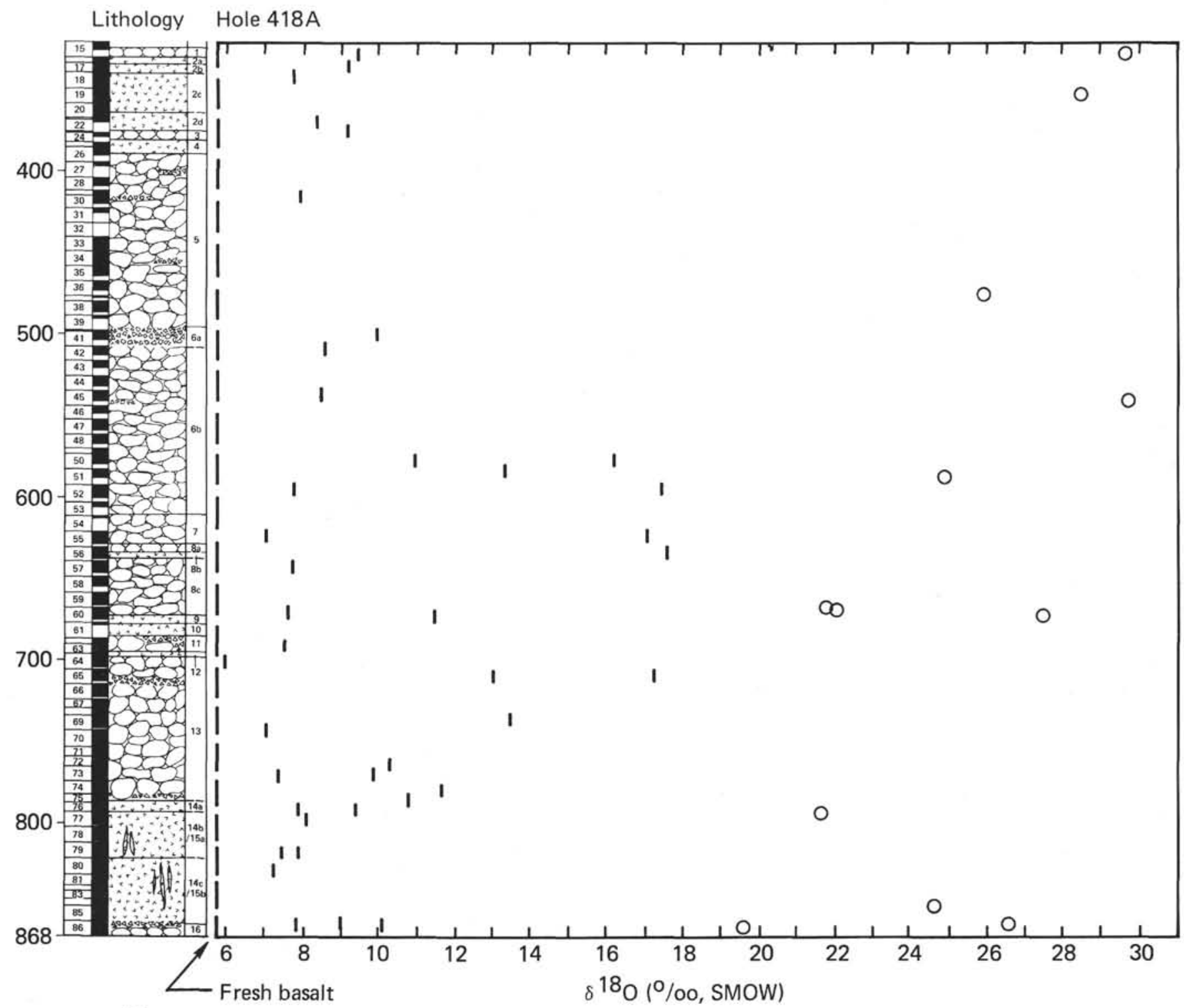

Figure 5. $\delta 180$ of basalts (bars) and carbonates (dots) from Hole $418 \mathrm{~A}$ as a function of depth and lithology. The dashed line at $5.8 \%$ represents the initial $\delta 180$ of unaltered basalts. Note that the most altered basalts are from the breccia zones and unit boundaries.

\section{ACKNOWLEDGMENTS}

Samples were provided by the shipboard party of Leg 53, Drs. Donnelly, Robinson, and Staudigel. Financial support was received from the Research Council of Canada. The assistance of Mrs. E. Toth is greatly acknowledged.

\section{REFERENCES}

Anderson, R.N., Hobart, M.A., and Longseth, M.G., 1978. Convective heat transfer in the oceanic crust and sediment on the flanks of mid-oceanic ridges in the Indian Ocean, EOS, Trans. Am. Geophys. Union, v. 59, p. 384.

Anderson, T.F. and Lawrence, J.R., 1976. Stable isotope investigations of sediments, basalts and authigenic phases from Leg 35 cores. In Hollister, C.D., Craddock, C., et al., Initial Reports of the Deep Sea Drilling Project, v. 35: Washington (U.S. Government Printing Office), p. 497-505.

Clayton, R.N. and Mayeda, T.K., 1963. The use of bromine pentafluoride in the extraction of oxygen from oxides and silicates for isotopic analysis, Geochim. Cosmochim. Acta, v. 27, p. 43-52.

Craig, H., 1957. Isotopic standards for carbon and oxygen and correction factors for mass-spectrometric analysis of carbon dioxide, Geochim. Cosmochim. Acta, v. 12, p. 133-149. , 1961. Standard for reporting concentrations of deuterium and oxygen-18 in natural waters, Science, v. 133, p. 1833-1834.

Garlick, D.G. and Dymond, J.R., 1970. Oxygen isotope exchange between volcanic materials and ocean water, Geol. Soc. Am. Bull., v. 81 , p. $2137-2143$.

Hart, R.A., 1973. A model for chemical exchange in the basalt-sea water system of oceanic Layer II, Canadian J. Earth Sci., v. 10 , p. $799-816$.

Hart, S.R., 1969. K, Rb, Cs contents and $\mathrm{K} / \mathrm{Rb}, \mathrm{K} / \mathrm{Cs}$ ratios of fresh and altered submarine basalts, Earth Planet. Sci. Lett., v. 6 , p. $295-303$.

Houtz, R. and Ewing, J., 1976. Upper crustal structure as a function of plate age, J. Geophys. Res., v. 81 , p. 2440-2498. 


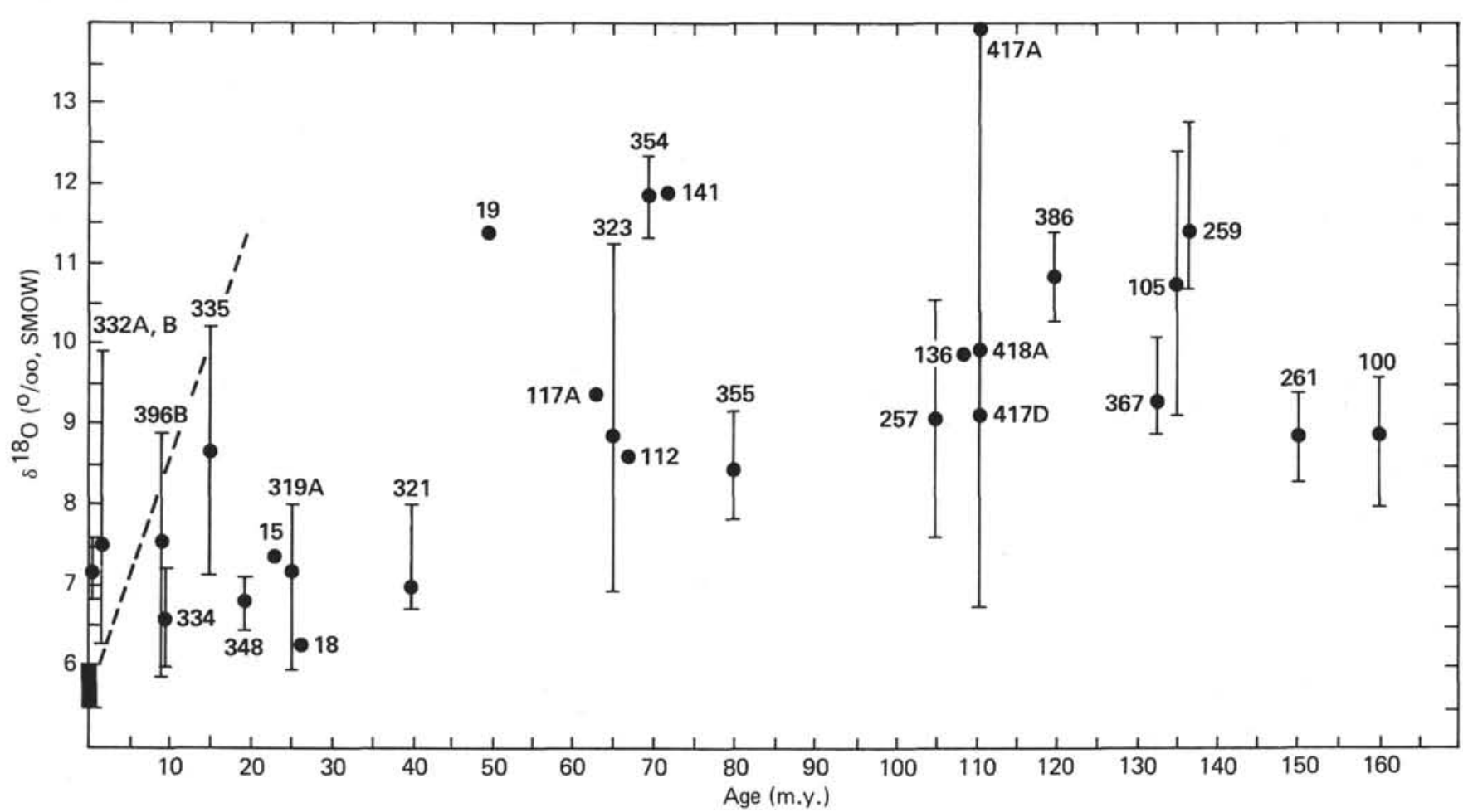

Figure 6. $\delta^{18} \mathrm{O}$ of basalts from DSDP sites versus age of the rock as estimated from information given in the Initial Reports. Length of the bars represents total range of $18 \mathrm{O}$ found whereas the dot is the average value. Box at zero age delimits the ${ }_{\delta}^{18} \mathrm{O}$ of fresh basalt. The dashed line is the weathering trend found in dredged basalts (Muehlenbachs and Clayton, 1972a). Data from Muehlenbachs (1976, 1977a, b), Anderson and Lawrence (1976) and this report.

Lawrence, J.R., Gieskes, J.M., and Broecker, W.S., 1975. Oxygen isotope and cation composition of DSDP pore waters and the alteration of Layer II basalts, Earth Planet. Sci. Lett., v. 27, p. $1-10$.

McCrea, J.M., 1950. On the isotopic chemistry of carbonates and a paleotemperature scale, J. Chem. Phys., v. 18, p. 849-857.

Muehlenbachs, K., 1974. Oxygen isotope geochemistry of DSDP Leg 34 basalts, Geol. Soc. Am. Abstr. Program, v. 6, p. 881882.

, 1976. Oxygen isotope geochemistry of DSDP Leg 34 basalts. In Hart, S.R., Yeats, R.S., et al, Initial Reports of the Deep Sea Drilling Project, v. 34: Washington (U.S. Government Printing Office), p. 377-340.

, 1977a. Oxygen isotope geochemistry of rocks from DSDP Leg 37, Canadian J. Earth Sci., v. 14, p. 771-776. , 1977b. Low temperature oxygen isotope exchange between the oceanic crust and sea water, Second Int. Water-Rock Interaction Symp. Proc., Strasbourg, France, August 7-25, 1977, p. 1317-1326.

Muehlenbachs, K. and Clayton, R.N., 1972a. Oxygen isotope studies of fresh and weathered submarine basalts, Canadian $J$. Earth Sci., v. 9, p. 172-184. , 1972b. Oxygen isotope geochemistry of submarine greenstones, Canadian J. Earth Sci., v. 9, p. 471-478. , 1976. Oxygen isotope composition of the oceanic crust and its bearing on sea water, J. Geophys. Res., v. 81, p. $4365-4369$.
Muehlenbachs, K. and Hodges, F.N., 1978. Oxygen isotope geochemistry of rocks from DSDP Leg 46. In Dmitriev, L., Heirtzler, J., et al., Initial Reports of the Deep Sea Drilling Project, v. 46: Washington (U.S. Government Printing Office), p. 257-258.

O'Neil, J.R., Adami, L.H., and Epstein, S., 1975. Revised value for the $\mathrm{O}^{18}$ fractionation between $\mathrm{CO}_{2}$ and $\mathrm{H}_{2} \mathrm{O}$ at $25^{\circ} \mathrm{C}, J$. Res., U.S. Geol. Surv., v. 3, p. 623-624.

O'Neil, J.R., Clayton, R.N., and Mayeda, T.K., 1969. Oxygen isotope fractionation in divalent metal carbonates, J. Chem. Phys., v. 51, p. 5547-5558.

Pineau, F., Javoy, M., Hawkins, J.W., and Craig, H., 1976. Oxygen isotope variations in marginal basins and ocean-ridge basalts, Earth Planet. Sci. Lett., v. 28, p. 299-307.

Savin, S.M. and Epstein, S., 1970. The oxygen and hydrogen isotope geochemistry of ocean sediments and shales, Geochim. Cosmochim. Acta, v. 34, p. 43-63.

Stakes, D.S. and O'Neil, J.R., 1977. Stable isotope composition of hydrothermal minerals from altered rocks from the East Pacific Rise and Mid-Atlantic Ridge, EOS, Trans. Am. Geophys. Union, v. 58, p. 1151.

Taylor, H.P., Jr., 1968. The oxygen isotope geochemistry of igneous rocks, Contrib. Mineral. Petrol., v. 19, p. 1-71.

Whitmarsh, R.B., 1978. Seismic refraction studies of the upper igneous crust in the North Atlantic and porosity estimates for Layer 2, Earth Planet. Sci. Lett., v. 37, p. 451-464. 